\title{
Research Paper \\ The Effect of Management Information System in Transition to Smart Organizations/ An Analytical study at Al-Qalam University College
}

Journal of

TANMIYAT ALRAFIDAIN

\section{(TANRA)}

A scientific, quarterly, international, open access, and peer-reviewed journal

Vol. 40, No. 130

June 2021

(C) University of Mosul |

College of Administration and Economics, Mosul, Iraq.

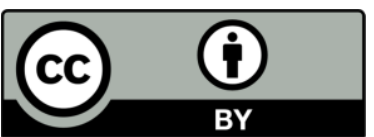

TANRA retain the copyright of published articles, which is released under a "Creative Commons Attribution License for CC-BY-4.0" enabling the unrestricted use, distribution, and reproduction of an article in any medium, provided that the original work is properly cited.

Citation: Shuaib Mohammed Abdo. (2021). "The Effect of Management Information System in Transition to Smart Organizations/ An Analytical study at Al-Qalam University College". TANMIYAT AL-RAFIDAIN, 39 (126), 231 -257,

https://doi.org/

10.33899/tanra.2020.128117.10

49

P-ISSN: 1609-591X

e-ISSN: 2664-276X

tanmiyat.mosuljournals.com

\section{Shuaib Mohammed Abdo ${ }^{1}$}

${ }^{1}$ Al-Qalam University College

Corresponding author: Shuaib Mohammed Abdo, Al-Qalam University College, Shuaeb.ma@alqalam.edu.iq .

DOI: https://doi.org/ 10.33899/tanra.2020.128117.1049

Article History: Received: 12/8/2020; Revised: 18/9/2020; Accepted: 30/9/2021; Published: 1/6/2021.

\section{Abstract}

The current study aims at identifying the effect of Management Information System on the transformation of universities and smart colleges from the viewpoint of the employees of the AL-Qalam University College / Kirkuk. The research has used the descriptive analytical method, and the questionnaire was the main tool for collecting data from the research community, which consists of (40) members of the academic and administrative staff in the college under study. The study reached a set of conclusions, namely:

1. Management Information System has an important and effective role in the transition to smart universities.

2. There is a positive correlation between Management Information System and the dimensions of transition to smart universities.

3. There is a positive effect relationship between Management Information System and the dimensions of transition to smart universities.

\section{Keywords}

Management Information System, Smart Organizations, Smart universities 


\section{ورقة بحثية \\ اثر نظم المعلومات الإدارية في التحول إلى المنظمات الأكية|

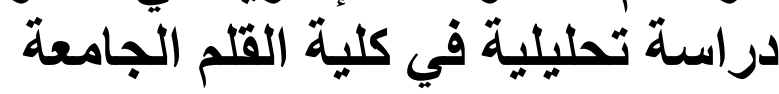

م.شعيب محمد شريف عبدو ' كلية القلم الجامعة/ قسم ادارة الاعمال

المؤلف المراسل: شعيب محمد شريف عبدو، كلية القلم الجامعة/ قسم ادارة الاعمال

Shuaeb.ma@alqalam.edu.iq

DOI: https://doi.org/ 10.33899/tanra.2020.128117.1049

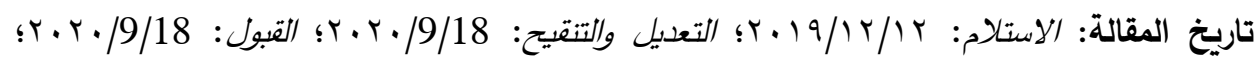

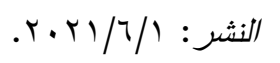

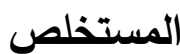

تهدف الدراسة الحالية إلى التعرف على أثر نظام الدعلومات الإدارية على تحول الجامعات والكليات الذكية

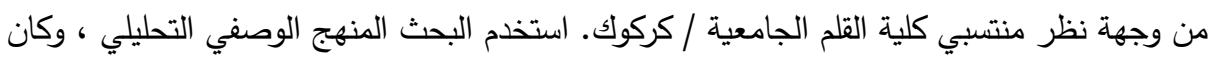

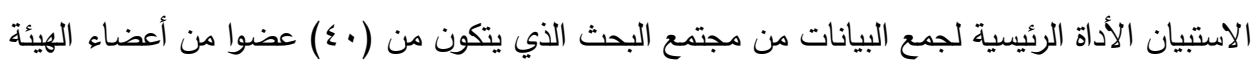
الأكاديمية والإدارية في الكلية قيد الدراسة.

1- نظام المعلومات الإدارية له دور مهم وفعال في التحول إلى الجامعات الذكية.

r- توجد علاقة ارتباط موجبة بين نظام المعلومات الإدارية وأبعاد الانتقال إلى الجامعات الذادئ لإدكية.

r- - توجد علاقة اثرية ايجابية بين نظام المعلومات الادارية وأبعاد التحول الى الجامعات الذكية.

الكلمات الرئيسة

نظام المعلومات الادارية، المنظمات الأكية، الجامعات الذكية.

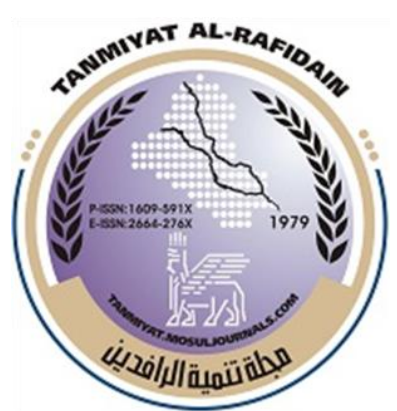

هبلة

\section{تنسيـة الرافدين}

(TANRA) دولية، مفتوحة الوصول، محكمة.

$$
\begin{aligned}
& \text { المجلد (••)، العدد (•r ( )؛ } \\
& \text { حزيران Ir.r }
\end{aligned}
$$

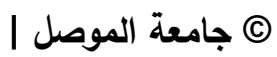
كلية الإدارة والاقتصاد، الموصل، العراق.

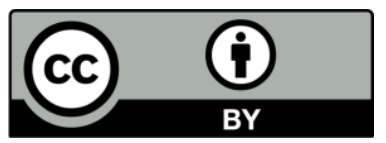

تحتفظ (TANRA) بحقوق الطبع والنشر للمقالات

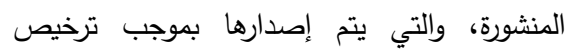

ل (Creative Commons Attribution) (CC-BY-4.0)

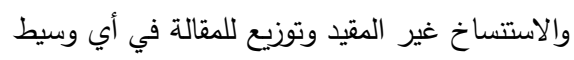
نقل، بشرط اقتباس العمل الأصلي بشكل صحيح.

الاقتباس: شعيب محمد شريف عبدو الإداربة

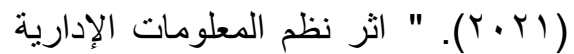

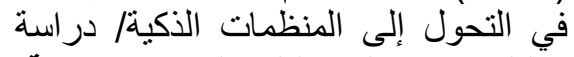
تحليلية في كلية القلم الجامعة". تنمية التية

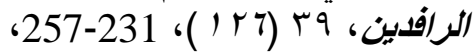

https://doi.org/

10.33899/tanra.2020.128117.10 49

P-ISSN: 1609-591X

e-ISSN: 2664-276X

tanmiyat.mosuljournals.com 


\section{Introduction:}

The rapid developments in the specified areas of systems, knowledge, the overall needs of business organizations in terms of technology, human resources, business processes and others have increased the importance of management information systems, and these systems are one of the most important means that contribute to the requirements of the dimensions of the transition to smart universities, which It is the modern trend in academic education in the world. The idea of switching to smart universities (especially private universities) came after the awareness of these institutions of the active role of modern systems to obtain the largest market share in the field of higher education.

Hence, the study explored the nature of the interrelationship between management information systems and the dimensions of transition to smart universities. To achieve this goal, the study was divided into four axes, the first included the methodology of the study, the second presented the theoretical framework of the study, the third touched on the applied framework of the study, and the fourth included conclusions and proposals.

\section{Methodological Framework of the Study (Methodology)}

\section{First: Statement of the Problem:}

Identifying the urgent need to integrate and use modern advanced methods in the educational process and linking all its processes, procedures and accomplishments using information and communication technology and to achieve the transition to smart universities as a sustainable competitive advantage, it was necessary to make the transition to smart universities of the most important goals and priorities of the management of these institutions. The idea of the research is to show the role of management information systems in the transition to smart universities through a key question (What is the effect of the use of management information systems in the dimensions of the transition to smart universities in Al-Qalam University College?) This question raised many subquestions:

1. What is the level of availability of Management Information System requirements in the researched college?

2. What is the level of availability of the dimensions of transition to smart universities in the researched college?

3. What is the effect of the availability of Management Information System requirements in the transition to smart universities?

\section{Second: Objectives of the study:}

The aim of the study is to identify the role of management information systems in the transition to smart universities in the researched college. 
1. Determine the availability of the requirements of management information systems in the researched college.

2. Diagnose the dimensions of transition to smart universities at the researched college.

3. Ensure the existence of a correlation between the management information systems and the dimensions of the transition to smart universities

4. Ensure the existence of an effect relationship between management information systems and the dimensions of the transition to smart universities.

5. Present a set of proposals based on the results of the study that would develop the variables of the Management Information System and the dimensions of the transition to the smart universities in the researched organization.

\section{Third: the significance of the study:}

The importance of the study is to address a vital issue required by the organizations, especially the Iraqi ones, as well as the importance that we summarize as follows:

1. The significance of the study stems from an attempt to provide a theoretical and practical framework for the variables of management information systems and the dimensions of the transition to smart universities, which will help the faculty administration to understand its contents.

The significance of the study is to provide the research college with accurate information on the level of availability of the requirements of management information systems and the need to strengthen each of these requirements.

3. Letting the faculty researched know about the level of availability of dimensions of transition to smart universities, and the need for this level of development as the basis of excellence.

4. The vital significance of its study variables (management information systems, smart universities) as contemporary approaches to the success of private colleges.

\section{Fourth: Study Model:}

Based on the problem of the study, , a model was designed in order to achieve the study objectives that depicts the nature of the relations between the study variables. Management information systems represent an independent variable while the dimensions of building smart universities represent an approved variable. 


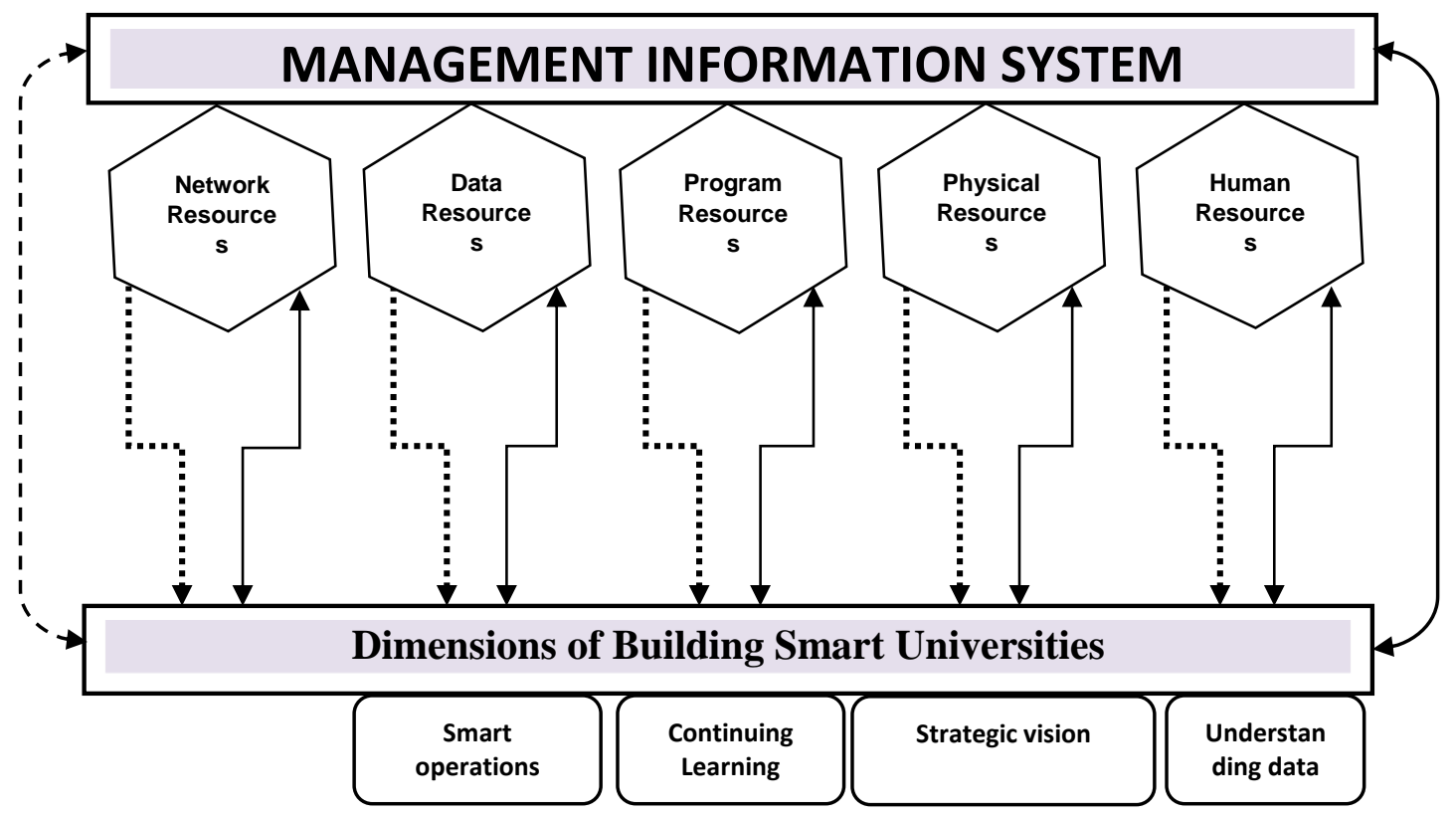

Figure (1) Study Model (prepared by the researcher)

Fifth: Study hypotheses:

The study examines the following hypotheses:

A- The first main hypothesis: There is a noteworthy correlation of statistical significance between the administrative information systems and the dimensions of the transition to smart universities at the macro level and its sub-dimensions level in the researched college.

1. There is a major correlation between human resources and the dimensions of transition to smart universities.

2. There is a significant correlation between material resources and the dimensions of transition to smart universities.

3. There is a major correlation between the software resources and the dimensions of the transition to smart universities.

4. There is a significant correlation between data resources and the dimensions of transition to smart universities.

5. There is a major correlation between network resources and the dimensions of transition to smart universities.

B - The second main hypothesis: There is a significant moral effect between the management information systems and the dimensions of the transition to smart

TANMIYAT AL-RAFIDAIN (P-ISSN: 1609-591X; E-ISSN: 2664-276X) تنمية الرافدين 
universities at the macro level and the level of its sub-dimensions in the researched organization.

1. There is a major relationship between human resources and the dimensions of transition to smart universities.

2. There is an important correlation between material resources and the dimensions of transition to smart universities.

3. There is an important relationship between the software resources and the dimensions of the transition to smart universities.

4. There is an important correlation between data resources and the dimensions of transition to smart universities.

5. There is an important correlation between network resources and the dimensions of transition to smart universities.

\section{Sixth: Methods of Data Collection:}

The study relied on the following methods of data collection and information:

1. Theoretical Methods: The researcher relied on the descriptive analytical methods of the most available Arabic and foreign sources such as books, studies, theses, scientific theses, publications, periodicals and researches directly related to the subject of the study, as well as the International Information Network (Internet).

2. Methods of the practical side: To complete this aspect, the researcher relied on the questionnaire form as the main means of collecting data and information. The questionnaire was designed according to the objectives and hypotheses of the study, including two main parts. The first part included the identifying information of the study sample. The (Likert) scale was used in determining the answer to the paragraphs of dimensions.

\section{Seventh: Study methodology:}

The study has adopted the descriptive - analytical methodology, because of the suitability of these approaches with the nature and objectives of the study, as it is characterized by the researcher close to reality and enable him to describe the phenomena accurately.

\section{Eighth: Tests of the validity of the study tool}

To ensure the validity of the study instrument, it has been subjected to the following tests:

1. The questionnaire stability test: To ensure that the questionnaire can be used as a measure of the dimensions of the current study, the test (Alpha-Cronbach / AlphaCronbach) was used for this purpose. Alpha-Kronbach at the level of the MIS variable (0.885), and the smart university variable obtained the value $(0.8926)$.

TANMIYAT AL-RAFIDAIN (P-ISSN: 1609-591X; E-ISSN: 2664-276X) تنمية الرافدين 
2. Test the validity of the content of the questionnaire: Internal consistency was used to prove the validity of the content, as the results of internal consistency indicated the existence of significant positive correlations between the variables of the questionnaire, which indicates the validity of the content of the questionnaire.

\section{Ninth: Methods adopted in statistical analysis:}

The ready-made software package (SPSS. Ver. 17) was used as the main tool in the statistical analysis of the study with a focus on the following statistical methods:

1. Frequencies, percentages, arithmetic averages and standard deviations to be used to describe and diagnose study variables.

2. Simple linear correlation was used to find correlations between study variables.

3. The simple regression method was used to find the effect relationships between the study variables.

4. The method of internal consistency was used to measure the accuracy of the resolution content.

5. The Alpha-Kronbach method was used to measure the resolution of the resolution.

\section{The Theoretical Framework of the Study}

First: The Concept of Management Information Systems:

A system is a set of elements that interact with each other in order to achieve a specific goal, usually consisting of systems of personnel, equipment and data. Information technology has helped to create systems that support managers, such as Management Information System, which have helped both individuals and the organization improve business to varying degrees, prompting organizations to promote investment in information technology (Yassin, Sharif, 2018, 62). Information systems are a combination of hardware, software and networks that work together to provide clear and accurate information to decision makers. (Valacich, and Schneider, 2010, 24).

Bidgoli $(2012,17)$ believes that information systems are a homogeneous and integrated organization consisting of hardware, software, human elements, data and others aimed at producing accurate information relevant to the subject matter of the decision and in a timely manner. It can be said that the information system is a set of components that work together to achieve a goal or set of multiple goals by receiving inputs and processing and provide the required outputs and orderly and then receive

TANMIYAT AL-RAFIDAIN (P-ISSN: 1609-591X; E-ISSN: 2664-276X) تنمية الرافدين 
feedback in case of deviations (Effy, 2009, 13). The development of information systems has led to the emergence of applications of new systems, including smart systems that allow direct interaction between the computer and the end user of the system without the need for mediation of information experts while using the system to support managers in the decision-making process (Abdo, 3013, 19).

Yassin $(2009,28)$ states that MIS is the system that manages, develops information technology that supports individuals and assists them in accomplishing tasks related to management, processing of data and information, as well as providing managers with the necessary reports. The orientation of information systems is usually about organizing the internal environment of organizations.

\section{Second: The importance of management information systems:}

The importance of knowledge management systems can be illustrated through its role in knowledge management processes, which are: (Yasin, 2010, 64), (Al-Otaibi, Al-Khafaf, 2012, 19) (Ghoneim, 2017, 1920).

1- Direct and indirect support for the management process from planning, organizing, steering, and controlling, as well as making and taking decisions.

2- Provide on time support to managers through direct dialogue between the manager and the information system.

3- Direct contribution in saving the cost, time and effort in providing the information necessary for making decisions.

4- Contribute to substantial and continuous improvement in the use of manpower and other resources of the organization.5. Revitalize and improve communication in the organization and provide more integrated information.

\section{Third: Types of Management Information Systems:}

There are several divisions adopted by the writers and researchers on defining the types of administrative information systems. Perhaps the most important of these divisions are Louden \& Louden, 2010, 43 which adopted the administrative levels as follows:

1. Operational Information Systems: which are the most important information systems in the organizations at the operational levels and are

TANMIYAT AL-RAFIDAIN (P-ISSN: 1609-591X; E-ISSN: 2664-276X) تنمية الرافدين 
computerized systems that provide routine daily reports such as sales and booking and others.

2. Management Information Systems: These are the systems that target the middle management in the organizations, and provide them with the required reports on the level of internal performance, and what distinguishes these systems is that they are oriented towards the internal environment.

3. Decision support systems: They are also systems that serve the middle management, but usually target the external environment of the organization such as competitors, prices and others.

4. Executive support systems: Information systems that serve senior management in organizations, especially supporting strategic decisions and decisions that need wisdom and analysis.

5. Expert Systems: These systems are designed to support managers in making difficult decisions and provide advice.

\section{Fourth: Elements of Management Information Systems:}

Most writers and researchers agreed in identifying the most important elements of information systems as the system cannot work without one of the following elements:

1. Human Resources: Human resources are the most important elements of management information systems and include programmers, analysts, designers, system operators and ultimate user (Ashour, 2009, 41).

2. Material Resources: These resources include computers and all related accessories of electronic devices (Effy, 2009, 162).

3. Software Resources: They are the overall programs that run the computer and are usually divided into two operating systems and application programs (Bidgoli, 2012, 50).

4. Data resources: The raw material of the facts being represented in (letters, numbers, forms, symbols) is stored for reference when needed (Gnaim, 2017, 22).

5. Network resources: ICTs are usually divided into external networks such as the Internet, and intranets such as Intranet (Yassin, 2010, 251)

Fifth: the concept of smart organizations (universities): 
those organizations that can achieve their goals in the most difficult circumstances, both internal and external environment through the development of knowledge of their members (Reidida, 2016, 15). It is also defined as those organizations that invest human talent and information technology to make the best investment in their actions to achieve the goals (Anzi, Saleh, 2009, 173)

Organizations are intelligent if they possess distinct human and cognitive abilities that enhance their ability to adapt to external environment variables, deal with the problems they face with high flexibility, and make strategic decisions in a timely manner (Ghneim, 2017, 27). Liu, et al., 2014, 3214) defines smart universities as an advanced mode of digital campus that provides the network everywhere by integrating innovation with the Internet to provide an integrated intelligent environment for the teacher and student as well as providing a common dialogue interface to provide information and knowledge of any place and time. Smart universities can be defined as smart organizations that are highly efficient educational institutions that use smart technology to make the learning process more efficient. It provides rich, interactive and everchanging learning environments that empower people and their behavior and encourage them to interact and collaborate. Increase student engagement and communication.

\section{Sixth: The importance and benefits of the smart university:}

The importance of smart universities in organizing communication between the elements of the educational process, and with educational services from anywhere and at any time, as well as solving the problems of traditional learning systems through the optimal use of technical resources. One of the benefits of smart universities is building an intellectual-minded, self-sufficient, self-learning, knowledge-based, intellectual-minded, innovative and creative person (http://en.unesco.org/themes/education21st).

\section{Seventh: Characteristics of the smart University:}

The most important characteristics of smart universities can be summarized as follows: Al-Awaini, 2016, 34 (Azarmi et al., 2010).

1. Non-compliance with space and time: The ability to access scientific content, from anywhere and at any time through modern communications devices and networks.

TANMIYAT AL-RAFIDAIN (P-ISSN: 1609-591X; E-ISSN: 2664-276X) تنمية الرافدين 
2. Self-reliance in learning: It is the personal privacy of education, and the organization of communication and cooperation in education among all parties concerned.

3. Easy access: Access to educational information and services, such as online learning systems, and more.

4. Technical Effectiveness: Technical competence provides the power of the University's IT infrastructure through cloud technologies, virtualization technologies, and others.

5. Openness: through the provision of open repositories of educational materials and sources of e-learning, and provide training in all disciplines, as well as free access to sources of scientific research.

\section{Eighth: The Difference between Intelligent Education and Traditional Education:}

Table 1 summarizes the following:

Table (1)

\section{Comparison between smart and Traditional Education}

\begin{tabular}{|l|l|l|l|}
\hline No & \multicolumn{1}{|c|}{ Standard } & \multicolumn{1}{|c|}{ Intelligent Learning } & \multicolumn{1}{|c|}{ Traditional Learning } \\
\hline 1 & Orientation & $\begin{array}{l}\text { Emphasize the future and } \\
\text { benefit from the past }\end{array}$ & Emphasis on past experiences \\
\hline 2 & The strategy & $\begin{array}{l}\text { Starting from the strategic } \\
\text { planning methodology }\end{array}$ & $\begin{array}{l}\text { Absence of strategic planning } \\
\text { methodology mostly }\end{array}$ \\
\hline 3 & Target & $\begin{array}{l}\text { Focus on building the power of } \\
\text { the mind }\end{array}$ & $\begin{array}{l}\text { Focus on building memory } \\
\text { power }\end{array}$ \\
\hline 4 & $\begin{array}{l}\text { Learning } \\
\text { Outcomes }\end{array}$ & $\begin{array}{l}\text { Emphasis on behavioral } \\
\text { practices }\end{array}$ & $\begin{array}{l}\text { Definition of behavioral } \\
\text { practices }\end{array}$ \\
\hline 5 & Style & $\begin{array}{l}\text { Integration of theoretical } \\
\text { education and training }\end{array}$ & $\begin{array}{l}\text { Separation between theoretical } \\
\text { education and training }\end{array}$ \\
\hline
\end{tabular}

Reference: Al-Awaini, Areej, 2016, Proposed Strategy for Transforming Palestinian Universities Towards Smart Universities in the Light of Knowledge Economy Requirements, Master Thesis, Islamic University, Gaza, p.26

Ninth: The dimensions of transformation to smart universities:

The dimensions of transformation to smart universities can be defined as follows:

TANMIYAT AL-RAFIDAIN (P-ISSN: 1609-591X; E-ISSN: 2664-276X) تنمية الرافدين 
1. Understanding the environment: It is intended to control the flow and flow of information from the internal and external environment of the University (Wheelen \& Hunter, 2010, 52).

2. Continuous learning: It means continuing to acquire knowledge through experience (Buchanan \& Huczynski, 2004, 110).

3. Strategic vision: It aims to analyze the environment and draw future plans for the university with the active participation of all parties.

4. Smart processes: It means providing the information to those who need it through participation in a timely manner, in order to raise the ability to address problems and crises in a timely manner.

5. Collective intelligence and teamwork: It means working in the spirit of a single team, especially in jobs that have challenges facing the university ( $\mathrm{Al}$ Rababah, 2016, 85-86).

\section{The third axis: the practical framework of the study}

First: Describing the characteristics of the study sample: After analyzing the data, it was found that the characteristics of the sample were as follows:

1. Gender: The study showed that the number of male respondents reached (30) or $(75 \%)$ while the number of females (10) or $(25 \%)$ of the total sample of the study as shown in table (4), and this indicator Positive, indicative of the diversity of ideas in the practice of college work and acceptance of women in leadership positions and encourage.

2. Age: Table (2) shows that the age group (25-35) constituted the highest percentage, reaching (50\%) of the respondents, followed by age group (36-45) by (25\%). The age group (46-55) (20\%), while the category (60 and above) received a percentage $(5 \%)$ of the total questionnaired opinions, which means that the college diversity in age groups in the management positions, which reflects positively on its work.

3. Academic Qualification: Table (2) shows that the highest percentage is for master's degree holders, reaching $(50 \%)$, while the percentage of holders of doctoral degree $(25 \%)$, and the percentage of holders of a bachelor's degree (20\%), while the percentage of holders of the higher diploma certificate $(5 \%)$, of the sample respondents, which indicates an acceptable balance in the academic achievement of the sample.

4. Duration of service (work experience): The study found that most of the respondents expressed their opinion of the service category (7-9) by $(50 \%)$, followed by the category (1-3), where the percentage (25\%), while the category got (4-6) on the percentage (20\%), and finally the percentage of the category (10 years and above) (5\%) of the respondents as shown in table (2), and these percentages indicate that the respondents have a great experience in the work

TANMIYAT AL-RAFIDAIN (P-ISSN: 1609-591X; E-ISSN: 2664-276X) تنمية الرافدين 
compared The age of the college does not exceed (11) years and this is a positive indicator.

5. Career Center: The study found that the percentage of department heads and rapporteurs is $(25 \%)$, followed by the percentage of divisional managers $(30 \%)$, followed by the proportion of managers of administrative units (20\%), as shown in table (2) and these The percentages are normal according to the hierarchy.

Table (2)

Distribution of respondents according to their characteristics

\begin{tabular}{|c|c|c|c|c|c|}
\hline & \multicolumn{2}{|c|}{ Female } & \multicolumn{2}{|c|}{ Male } & overall \\
\hline Repetition & \multicolumn{2}{|c|}{1.} & \multicolumn{2}{|c|}{$\overline{T r}$} & $\varepsilon \cdot$ \\
\hline Rate & \multicolumn{2}{|c|}{$\%$ Yro } & \multicolumn{2}{|c|}{$\%$ \%० } & $\% 1 \ldots$ \\
\hline $\begin{array}{c}\text { Academic } \\
\text { qualification }\end{array}$ & BA & $\begin{array}{c}\text { High } \\
\text { Diploma }\end{array}$ & MA & PhD & Overall \\
\hline Repetition & 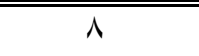 & $\overline{T r}$ & $r \cdot$ & 1. & $\varepsilon$. \\
\hline Rate & \%Y. & $\%{ }^{\circ}$ & $\% \circ$. & $\%$ YY & \%1.. \\
\hline Service period & $\begin{array}{l}\text { More than } \\
\text { 10years }\end{array}$ & $9-V$ & $7 . \varepsilon$ & $r-1$ & Overall \\
\hline Repetition & $\overline{\bar{r}}$ & $\overline{T .}$ & 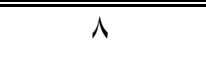 & 1. & $\varepsilon$. \\
\hline Rate & $\%{ }^{\circ}$ & $\% \%^{\circ}$ & $\overline{\% r}$. & $\%$ Yo & $\% 1 \ldots$ \\
\hline Age group & $\begin{array}{l}\text { More than } \\
60 \text { years }\end{array}$ & 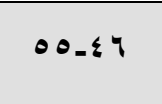 & \&O-M & ro_ro & Overall \\
\hline Repetition & $\overline{\Lambda \Lambda}$ & 1. & $\overline{r .}$ & $\bar{T}$ & $\varepsilon$. \\
\hline Rate & $\% r$. & $\%$ Yro & $\%{ }^{\circ}$ & $\% \circ$ & $\% 1 \ldots$ \\
\hline career center & $\begin{array}{l}\text { Unit } \\
\text { official }\end{array}$ & $\begin{array}{l}\text { Section } \\
\text { official }\end{array}$ & Rapporteur & $\begin{array}{l}\text { Dept. } \\
\text { Head }\end{array}$ & Overall \\
\hline Repetition & $\Lambda$ & Ir & 1. & 1. & $\varepsilon$. \\
\hline Rate & $\%$ \%r. & $\%$ \%r. & $\%$ Y\%o & $\%$ YO & $\%$ \\
\hline
\end{tabular}

TANMIYAT AL-RAFIDAIN (P-ISSN: 1609-591X; E-ISSN: 2664-276X) تنمية الرافدين 
Second: Description and Diagnosis of Study Variables:1. Description and diagnosis of the MIS variable: it is noted from Table (3) that the availability of the MIS variable in the college at the total level was (50.998\%) as a percentage of the respondents' agreement on the availability of indicators of this variable in the college with an average of (3.185) deviation. These results indicate that the research college applies MIS in its business, but the percentage of its application and availability is somewhat low, and that the college needs a higher level of the MIS variable that it possesses to be able to cope with changes in the contemporary business environment. .

Regarding the description and diagnosis of each of the variables of MIS, they are as follows:

a. Human Resources: Data from Table (3) indicate that $(84.17 \%)$ of the administrative leaders in the college are in agreement with the indicators of this variable, $9.17 \%$ of them are not in agreement, and (6.67\%) of them are neutral, with an average of 3.3833. ) and standard deviation (0.738). The most prominent indicators that contributed to the enrichment of this variable is $\mathrm{X} 3$, which states (employees participate in the analysis and design of information systems in the college) and the agreement (92.5\%) of the leaders surveyed and the mean arithmetic of (4) and standard deviation (0.599), and these results indicate that the college has an interest in engaging professionals in the analysis and design of information systems.

b. Physical resources: Table (3) indicates that (51.67\%) of the administrative leaders in the faculty are in agreement with the indicators of this variable and that $(24.99 \%)$ of them are not in agreement, and $(23.32 \%)$ of them were neutral, with an average of (3.275). and standard deviation (1.119). Among the most prominent indicators that contributed to the enrichment of this variable is X5, which states (available computers required for the work of information systems in the college.) With the agreement of $(75 \%)$ of the leaders surveyed and the mean arithmetic of (3.705) and standard deviation (1.109), and these results indicate that the college has little interest in providing the infrastructure to run information systems.

c. Software resources: Table (3) indicates that $(40.83 \%)$ of the administrative leaders in the researched college agree with the indicators of this variable and $(39.17 \%)$ of them are not in agreement, and (20\%) of them are neutral, with an average of (2.911). ) a standard deviation (1.154). The most prominent indicators that contributed to the enrichment of this variable is $\mathrm{X} 9$, which states that (the software used is compatible with the requirements of information systems in the college) and the agreement (50\%) of the leaders surveyed and the mean of (3.125) and standard deviation (1.066), and these results indicate that the research college has little interest in software resources.

d. Data Resources: Table (3) indicates that (42.5\%) of the administrative leaders at the research college are in agreement with the indicators of this variable and that

TANMIYAT AL-RAFIDAIN (P-ISSN: 1609-591X; E-ISSN: 2664-276X) تنمية الرافدين 
$(22.5 \%)$ of them are not in agreement, and $(35 \%)$ of them are neutral, with an average of (3.066). And standard deviation (1.077). One of the most prominent indicators that contributed to the enrichment of this variable is the X11, which states (the data has a quantitative aspect in the college.) These results indicate that the researched college has very little interest in the data resource because it does not have a central database for preservation.

e. Network resources: Data from Table (3) indicate that $(35.83 \%)$ of the administrative leaders in the college in question are in agreement with this indicator. And standard deviation (1.19). These results indicate that the research college has very little interest in network resources.

Table 3

Respondents' responses to the MIS variable

\begin{tabular}{|c|c|c|c|c|c|c|c|c|c|c|c|c|c|}
\hline \multirow{3}{*}{$\begin{array}{c}\text { Sub- } \\
\text { variant }\end{array}$} & \multirow{3}{*}{ Indexes } & \multicolumn{10}{|c|}{ Scale movement } & \multirow{3}{*}{$\begin{array}{l}\text { Arithmeti } \\
\text { c mean }\end{array}$} & \multirow{3}{*}{$\begin{array}{c}\text { Standar } \\
\text { d } \\
\text { deviatio } \\
\mathbf{n}\end{array}$} \\
\hline & & \multicolumn{2}{|c|}{$\begin{array}{c}\begin{array}{c}\text { Strongly } \\
\text { agree }\end{array} \\
\text { 。 }\end{array}$} & \multicolumn{2}{|c|}{$\begin{array}{c}\text { agree } \\
\leq\end{array}$} & \multicolumn{2}{|c|}{$\begin{array}{c}\text { Neutral } \\
r\end{array}$} & \multicolumn{2}{|c|}{$\begin{array}{c}\text { Do not } \\
\text { agree } \\
r\end{array}$} & \multicolumn{2}{|c|}{$\begin{array}{c}\text { Strongly } \\
\text { Do not } \\
\text { agree } \\
1\end{array}$} & & \\
\hline & & $\begin{array}{l}\text { I } \\
\text { D }\end{array}$ & $\%$ & ID & $\%$ & ID & $\%$ & ID & $\%$ & ID & $\%$ & & \\
\hline \multirow{3}{*}{$\begin{array}{c}\text { Human } \\
\text { resource } \\
\mathrm{S}\end{array}$} & $\begin{array}{l}: X_{1} \\
\text { experience } \\
\text { qualifications of } \\
\text { information } \\
\text { system workers } \\
\text { are commensurate } \\
\text { with their assigned } \\
\text { tasks }\end{array}$ & r & $\bullet$ & $\begin{array}{l}\mathrm{r} \\
1\end{array}$ & $V V, 0$ & $\bullet$ & $1 Y, 0$ & $r$ & $\bullet$ & - & - & $r, \wedge r \bullet$ & $\cdot, 09 \varepsilon$ \\
\hline & $\begin{array}{l}\text { c: Continuous } \\
\text { training courses } \\
\text { are available for } \\
\text { staff at the } \\
\text { College }\end{array}$ & $\bullet$ & $1 Y, 0$ & $\begin{array}{l}Y \\
7\end{array}$ & 70 & r & $\bullet$ & $\bullet$ & $1 Y, 0$ & Y & $\bullet$ & $r, \neg \vee 0$ & $1, \cdot r r$ \\
\hline & $\begin{array}{l}\text { X3: Staff } \\
\text { participate in } \\
\text { the analysis and } \\
\text { design on } \\
\text { information } \\
\text { systems in the } \\
\text { college }\end{array}$ & $\bullet$ & $1 Y, 0$ & $\begin{array}{l}r \\
r\end{array}$ & $\Lambda$. & 1 & $r, 0$ & $r$ & $\bullet$ & - & - & $\varepsilon$ &., 099 \\
\hline Rate & - & - & $1 \cdot$ & - & $\begin{array}{c}V \varepsilon, 1 \\
V\end{array}$ & - & $7,7 V$ & - & $v, \bullet$ & - & $1,7 \mathrm{~V}$ & r & • , VNA \\
\hline Overall & $r$ & \multicolumn{4}{|c|}{$\Lambda \varepsilon, 1 \vee$} & \multicolumn{2}{|c|}{$7,7 V$} & \multicolumn{4}{|c|}{$9,1 V$} & - & - \\
\hline $\begin{array}{c}\text { Material } \\
\text { resource } \\
\mathbf{S}\end{array}$ & $\begin{array}{l}\text { X4: There are } \\
\text { input and } \\
\text { output devices } \\
\text { suitable for the } \\
\text { work of } \\
\text { information }\end{array}$ & r & $\bullet$ & $\begin{array}{l}1 \\
1\end{array}$ & $\leqslant 0$ & $\begin{array}{l}1 \\
r\end{array}$ & $\mu$ & $\bullet$ & $1 Y, 0$ & $\boldsymbol{r}$ & $v, 0$ & $r, r \vee 0$ & $1,1 r$ \\
\hline
\end{tabular}

TANMIYAT AL-RAFIDAIN (P-ISSN: 1609-591X; E-ISSN: 2664-276X) تنمية الرافدين 
Abdo

\begin{tabular}{|c|c|c|c|c|c|c|c|c|c|c|c|c|c|}
\hline \multirow{3}{*}{$\begin{array}{l}\text { Sub- } \\
\text { variant }\end{array}$} & \multirow{3}{*}{ Indexes } & \multicolumn{10}{|c|}{ Scale movement } & \multirow{3}{*}{$\begin{array}{l}\text { Arithmeti } \\
\text { c mean }\end{array}$} & \multirow{3}{*}{$\begin{array}{c}\text { Standar } \\
\text { d } \\
\text { deviatio } \\
\mathbf{n}\end{array}$} \\
\hline & & \multicolumn{2}{|c|}{$\begin{array}{c}\begin{array}{c}\text { Strongly } \\
\text { agree }\end{array} \\
\text { 。 }\end{array}$} & \multicolumn{2}{|c|}{$\begin{array}{c}\text { agree } \\
\varepsilon\end{array}$} & \multicolumn{2}{|c|}{$\begin{array}{c}\text { Neutral } \\
r\end{array}$} & \multicolumn{2}{|c|}{$\begin{array}{c}\text { Do not } \\
\text { agree } \\
r\end{array}$} & \multicolumn{2}{|c|}{$\begin{array}{c}\text { Strongly } \\
\text { Do not } \\
\text { agree } \\
1\end{array}$} & & \\
\hline & & $\begin{array}{l}\text { I } \\
\text { D }\end{array}$ & $\%$ & ID & $\%$ & ID & $\%$ & ID & $\%$ & ID & $\%$ & & \\
\hline & $\begin{array}{l}\text { systems in the } \\
\text { college }\end{array}$ & & & & & & & & & & & & \\
\hline & $\begin{array}{l}\text { X5: Computer } \\
\text { equipment } \\
\text { required for } \\
\text { the work of } \\
\text { information } \\
\text { systems in the } \\
\text { college. }\end{array}$ & $\Lambda$ & $r \cdot$ & $\begin{array}{l}r \\
r\end{array}$ & 00 & $\varepsilon$ & 1. & $r$ & $V, 0$ & $r$ & $V, 0$ & $r, v Y 0$ & $1,1 \cdot 9$ \\
\hline & $\begin{array}{l}\text { X6: } \\
\text { Management is } \\
\text { keen to keep } \\
\text { abreast of } \\
\text { developments } \\
\text { in the technical } \\
\text { field. }\end{array}$ & $\varepsilon$ & 1. & $\wedge$ & $r$. & $\begin{array}{l}1 \\
r\end{array}$ & $\mu$. & 9 & $Y Y, 0$ & V & IV, 0 & $r, \wedge Y_{0}$ & $1, r \mu \wedge$ \\
\hline Average & - & - & $\begin{array}{c}11,7 \\
8\end{array}$ & - & $\varepsilon$. & - & $\begin{array}{c}r r, r \\
r\end{array}$ & - & $\begin{array}{c}1 \leq, 1 \\
7\end{array}$ & - & $\begin{array}{c}1 \cdot, 1 \\
r\end{array}$ & $r, r \vee 0$ & 1,119 \\
\hline Total & $r$ & & & $7 V$ & & & $r, r r$ & & & 99 & & - & - \\
\hline \multirow{3}{*}{$\begin{array}{l}\text { Softwar } \\
\text { e } \\
\text { resource } \\
\text { s }\end{array}$} & $\begin{array}{l}\text { : X7 protection } \\
\text { softwares are } \\
\text { available to } \\
\text { prevent } \\
\text { systems } \\
\text { penetration in } \\
\text { the college }\end{array}$ & $r$ & $\bullet$ & $\begin{array}{l}1 \\
r\end{array}$ & $M r, 0$ & 7 & 10 & $\begin{array}{l}1 \\
\varepsilon\end{array}$ & ro & 0 & $1 Y, 0$ & r,A Yo & $1,1 \vee \varepsilon$ \\
\hline & $\begin{array}{l}\text { X8: All } \\
\text { instructions for } \\
\text { operating } \\
\text { systems are } \\
\text { available in the } \\
\text { college. }\end{array}$ & $\varepsilon$ & 1. & $\begin{array}{l}1 \\
.\end{array}$ & ro & $\wedge$ & $r$. & $\begin{array}{l}1 \\
r\end{array}$ & $r Y, 0$ & 0 & $1 Y, 0$ & $\curlyvee, \vee \wedge \bullet$ & $1, r Y r$ \\
\hline & $\begin{array}{l}\text { The software } \\
\text { used meets the } \\
\text { requirements } \\
\text { of information } \\
\text { systems }\end{array}$ & - & - & $\begin{array}{l}r \\
\cdot\end{array}$ & 0. & $\begin{array}{l}1 \\
\cdot\end{array}$ & Yo & $\bullet$ & $1 Y, 0$ & 0 & $1 Y, 0$ & $r, 1$ ro & $1, .77$ \\
\hline Average & - & - & $\bullet$ & - & $\begin{array}{c}\mu \theta, \Lambda \\
\mu\end{array}$ & - & r. & - & $\begin{array}{c}r Y, q \\
Y\end{array}$ & - & $1 Y, 0$ & $r, q 11$ & $1,10 \leq$ \\
\hline Total & $r$ & \multicolumn{4}{|c|}{$\varepsilon \cdot, \wedge r$} & \multicolumn{2}{|r|}{$r$. } & \multicolumn{4}{|c|}{$r q, 1 v$} & - & - \\
\hline $\begin{array}{c}\text { Data } \\
\text { resource }\end{array}$ & $\begin{array}{l}\text { X10 There is } \\
\text { no repetition } \\
\text { of data used in } \\
\text { information }\end{array}$ & - & - & $\begin{array}{l}1 \\
v\end{array}$ & $\varepsilon r, 0$ & $\begin{array}{l}1 \\
r\end{array}$ & $r$. & 0 & $1 Y, 0$ & 7 & 10 & $r$ & $1, \cdot \wedge 7$ \\
\hline
\end{tabular}


Abdo

\begin{tabular}{|c|c|c|c|c|c|c|c|c|c|c|c|c|c|}
\hline \multirow{3}{*}{$\begin{array}{c}\text { Sub- } \\
\text { variant }\end{array}$} & \multirow{3}{*}{ Indexes } & \multicolumn{10}{|c|}{ Scale movement } & \multirow{3}{*}{$\begin{array}{l}\text { Arithmeti } \\
\text { c mean }\end{array}$} & \multirow{3}{*}{$\begin{array}{c}\text { Standar } \\
\text { d } \\
\text { deviatio } \\
\mathbf{n}\end{array}$} \\
\hline & & \multicolumn{2}{|c|}{$\begin{array}{c}\text { Strongly } \\
\text { agree } \\
\text { - }\end{array}$} & \multicolumn{2}{|c|}{$\begin{array}{c}\text { agree } \\
\leq\end{array}$} & \multicolumn{2}{|c|}{$\begin{array}{c}\text { Neutral } \\
r\end{array}$} & \multicolumn{2}{|c|}{$\begin{array}{l}\text { Do not } \\
\text { agree } \\
r\end{array}$} & \multicolumn{2}{|c|}{$\begin{array}{c}\text { Strongly } \\
\text { Do not } \\
\text { agree } \\
1\end{array}$} & & \\
\hline & & $\begin{array}{l}\text { I } \\
\text { D }\end{array}$ & $\%$ & ID & $\%$ & ID & $\%$ & ID & $\%$ & ID & $\%$ & & \\
\hline \multirow[t]{3}{*}{$\mathbf{S}$} & systems & & & & & & & & & & & & \\
\hline & $\begin{array}{l}\text { X11: The data } \\
\text { have a } \\
\text { quantitative } \\
\text { aspect in the } \\
\text { college. }\end{array}$ & r & • & $\begin{array}{l}1 \\
v\end{array}$ & $\varepsilon r, 0$ & $\begin{array}{l}1 \\
\varepsilon\end{array}$ & ro & $r$ & $\bullet$ & 0 & $\mid r, 0$ & r, rro & $1, \cdot v r$ \\
\hline & $\begin{array}{l}\text { X12: The } \\
\text { college has a } \\
\text { central } \\
\text { database that } \\
\text { stores all its } \\
\text { data }\end{array}$ & - & - & $\begin{array}{l}1 \\
0\end{array}$ & $r v, 0$ & $\begin{array}{l}1 \\
7\end{array}$ & $\varepsilon$. & $r$ & 0 & $v$ & IV,0 & 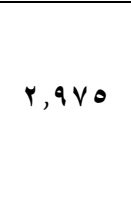 & $1, \cdot V r$ \\
\hline Average & - & - & $1,7 v$ & - & $\begin{array}{c}\varepsilon \cdot \Lambda \\
\mu\end{array}$ & - & ro & - & $v, 0$ & - & 10 & $r, .77$ & $1, \cdot v V$ \\
\hline Total & $r$ & & &, 0 & & & 0 & & &, 0 & & - & - \\
\hline \multirow{3}{*}{$\begin{array}{c}\text { Network } \\
\text { resource } \\
\mathrm{S}\end{array}$} & $\begin{array}{l}\text { X13: The } \\
\text { networks } \\
\text { available in } \\
\text { the College } \\
\text { are } \\
\text { commensurat } \\
\text { e with } \\
\text { business } \\
\text { needs. }\end{array}$ & $r$ & $\bullet$ & $\begin{array}{l}1 \\
0\end{array}$ & $r V, 0$ & $\wedge$ & $r \cdot$ & ! & ro & 0 & $1 Y, 0$ & r,q\० & 1,170 \\
\hline & $\begin{array}{l}\text { X14: The } \\
\text { networks } \\
\text { available in } \\
\text { the college } \\
\text { perform their } \\
\text { work with } \\
\text { the required } \\
\text { efficiency. }\end{array}$ & - & - & $\begin{array}{l}1 \\
1\end{array}$ & $r v, 0$ & $\frac{1}{7}$ & $\varepsilon$. & $\varepsilon$ & $1 \cdot$ & 9 & $r r, 0$ & Y,VYO & $1,1 \cdot 9$ \\
\hline & $\begin{array}{l}\text { X15: } \\
\text { Networks are } \\
\text { maintained } \\
\text { in the college } \\
\text { continuously }\end{array}$ & r & 0 & $\begin{array}{l}1 \\
r\end{array}$ & $M r, 0$ & $\begin{array}{l}1 \\
r\end{array}$ & r. & $r$ & 0 & $\begin{array}{l}1 \\
1\end{array}$ & $r v, 0$ & $r, \wedge Y \bullet$ & $1, Y q \wedge$ \\
\hline Average & - & - & $r, r \mu$ & - & $r Y, 0$ & - & $r$. & - & $\begin{array}{c}1 \mu, r \\
\mu\end{array}$ & - & $\begin{array}{c}r_{\bullet}, \Lambda \\
r\end{array}$ & $r, \Lambda \leq \varepsilon$ & $1,19$. \\
\hline Total & $r$ & & & $\Lambda T$ & & & . & & & IV & & - & - \\
\hline
\end{tabular}




\begin{tabular}{|c|c|c|c|c|c|c|c|c|c|c|c|c|c|}
\hline \multirow{3}{*}{$\begin{array}{c}\text { Sub- } \\
\text { variant }\end{array}$} & \multirow{3}{*}{ Indexes } & \multicolumn{10}{|c|}{ Scale movement } & \multirow{3}{*}{$\begin{array}{l}\text { Arithmeti } \\
\text { c mean }\end{array}$} & \multirow{3}{*}{$\begin{array}{c}\text { Standar } \\
\text { d } \\
\text { deviatio } \\
n\end{array}$} \\
\hline & & \multicolumn{2}{|c|}{$\begin{array}{c}\text { Strongly } \\
\text { agree } \\
0\end{array}$} & \multicolumn{2}{|c|}{$\begin{array}{c}\text { agree } \\
\varepsilon\end{array}$} & \multicolumn{2}{|c|}{$\begin{array}{c}\text { Neutral } \\
r\end{array}$} & \multicolumn{2}{|c|}{$\begin{array}{c}\text { Do not } \\
\text { agree } \\
r\end{array}$} & \multicolumn{2}{|c|}{$\begin{array}{c}\text { Strongly } \\
\text { Do not } \\
\text { agree } \\
\text { । }\end{array}$} & & \\
\hline & & $\begin{array}{l}\text { I } \\
\text { D }\end{array}$ & $\%$ & ID & $\%$ & ID & $\%$ & ID & $\%$ & ID & $\%$ & & \\
\hline $\begin{array}{c}\text { Overall } \\
\text { index }\end{array}$ & 10 & \multicolumn{4}{|c|}{$0 ., 991$} & \multicolumn{2}{|c|}{ rr } & \multicolumn{4}{|c|}{$Y 0,991$} & $r, 1 \wedge 0$ & 1,00 \\
\hline
\end{tabular}

3. Describing and diagnosing the variable dimensions of building smart universities: We note from Table (4) that $(36.61 \%)$ of the administrative leaders in the researched college are in agreement with the indicators of this variable and that $(20.18 \%)$ of them are not in agreement, and $(43.21 \%)$ of them were neutral, This is by means of a mean of 3.164 and a standard deviation of 0.87 . These results indicate that the overall level of availability of the variable dimensions of building smart universities is $(36.61 \%)$ and this level is very low and the reason for this may be due to the lack of awareness of the importance of smart universities, so the college must increase its interest and more effectively and seriously to raise the level of variable dimensions of building smart universities through the application of its steps and adoption of the concept and awareness of its foundations, and increase the awareness of administrative leaders and workers of its importance to the College.

With regard to the description and diagnosis of each of the variables of the strategic change are as follows:

4. Understanding the Environment: Data from Table (4) indicate that (47.5\%) of the administrative leaders in the researched college agree with the indicators of this variable and that $(15 \%)$ of them are not in agreement, and $(37.5 \%)$ of them are neutral, with an average of 3.312. ) standard deviation (0.908). These results indicate that there is some weakness in the application of this variable in the researched college, due to the instability of the college environment.

5. Strategic Vision: Data from Table (4) indicate that (40\%) of the administrative leaders in the faculty are in agreement with the indicators of this variable and that $(26.25 \%)$ of them are not in agreement, and $(33.75 \%)$ of them were neutral, with an arithmetic average of (3.15). standard deviation (0.954). These results indicate that there is some weakness in the application of this variable in the researched college, because of the lack of interest of the researched faculty to conceptualize what the future college might be.

6. Continuous Learning: Data from Table (4) indicate that $(36.25 \%)$ of the administrative leaders in the research college are in agreement with the indicators of this variable and that $(26.25 \%)$ of them are not in agreement, and $(37.5 \%)$ of

TANMIYAT AL-RAFIDAIN (P-ISSN: 1609-591X; E-ISSN: 2664-276X) تنمية الرافدين 
them are neutral, with an arithmetic mean of (3.012). ) standard deviation (0.939). These results indicate that there is some weakness in the application of this variable in the researched college, because the researched faculty does not realize the benefits it will achieve from the continuous learning process.

7. Smart operations: Table (4) indicates that (28.75\%) of the administrative leaders in the faculty interviewed agree with the indicators of this variable and that $(27.5 \%)$ of them are not in agreement, and $(43.75 \%)$ of them were neutral, with an average of (2.9). ) standard deviation (0.936). These results indicate that there is some weakness in the application of this variable in the researched college, due to the lack of interest of the researched college in smart operations, which reflected negatively on the application of this variable.

8. Collective Intelligence: Table (4) indicates that $(32.5 \%)$ of the administrative leaders in the researched college agree with the indicators of this variable and that $(13.75 \%)$ of them are not in agreement, and $(53.75 \%)$ of them were neutral, with an average of (3.162). ) standard deviation (0.711). These results indicate a significant weakness in the application of this variable in the researched college, due to the lack of specialists and distinguished in the creative side, and the lack of motivation of workers to work together.

9. Looking at the results of the above strategic change variables, it is noted that all these variables suffer from weak implementation in the college, and this may be due to the lack of special training courses in the field of modern technological developments, as well as perhaps due to the conditions of the unstable work environment, as well as the large number of changes and acceleration in That has made the desire of administrative leaders to adopt the same methods of work, but the college must be aware that the dimensions of building smart colleges is one of the most important entry points for the transition to smart universities.

Table 4

Responses of people surveyed about the variable dimensions of building smart universities

\begin{tabular}{||c|c|c|c|c||}
\hline \multirow{2}{*}{ Indexes } & Scale movement & $\begin{array}{c}\text { Arithmeti } \\
\text { c mean }\end{array}$ & $\begin{array}{c}\text { d } \\
\text { deviatio } \\
\text { n }\end{array}$ \\
& & 0 & $\varepsilon$ \\
\hline
\end{tabular}

TANMIYAT AL-RAFIDAIN (P-ISSN: 1609-591X; E-ISSN: 2664-276X) تنمية الرافدين 
Abdo

\begin{tabular}{|c|c|c|c|c|c|c|c|c|c|c|c|c|c|}
\hline \multirow[t]{2}{*}{ Sub-variant } & & \multicolumn{2}{|c|}{$\begin{array}{c}\text { Strongl } \\
\text { y agree } \\
\bullet\end{array}$} & \multicolumn{2}{|c|}{$\begin{array}{c}\text { agree } \\
\varepsilon\end{array}$} & \multicolumn{2}{|c|}{ Neutral } & \multicolumn{2}{|c|}{$\begin{array}{c}\text { Do not } \\
\text { agree } \\
r\end{array}$} & \multicolumn{2}{|c|}{$\begin{array}{c}\text { Strongly } \\
\text { Do not } \\
\text { agree } \\
1\end{array}$} & & \\
\hline & & ID & $\%$ & ID & $\%$ & ID & $\%$ & $\begin{array}{l}\text { I } \\
\text { D }\end{array}$ & $\%$ & $\begin{array}{l}\text { I } \\
\text { D }\end{array}$ & $\%$ & & \\
\hline \multirow{2}{*}{$\begin{array}{l}\text { Understandin } \\
\text { g the } \\
\text { surrounding } \\
\text { environment }\end{array}$} & $\begin{array}{l}\text { X16: Total } \\
\text { environmenta } \\
1 \text { uncertainties } \\
\text { are accurately } \\
\text { diagnosed }\end{array}$ & - & - & $\begin{array}{l}1 \\
0\end{array}$ & $r v, 0$ & $\begin{array}{l}1 \\
\Lambda\end{array}$ & $\leq 0$ & $r$ & $\bullet$ & 0 & $1 Y, 0$ & $r, \cdot v o$ & $\cdot, 9 \vee 1$ \\
\hline & $\begin{array}{l}\text { X17: } \\
\text { Environmenta } \\
1 \text { uncertainties } \\
\text { are taken into } \\
\text { account when } \\
\text { making } \\
\text { decisions at } \\
\text { the college }\end{array}$ & $\varepsilon$ & 1. & $\frac{1}{9}$ & $\varepsilon V, 0$ & $\begin{array}{l}1 \\
r\end{array}$ & $r$ & $\bullet$ & $1 r, 0$ & - & - & $\Gamma, 00$. & $\cdot, \wedge \leq 0$ \\
\hline Average & - & - & 0 & - & $\varepsilon Y, 0$ & - & $r v, 0$ & - & $\Lambda, \vee 0$ & - & $7, Y 0$ & $r, r, r$ & $\cdot, 9 \cdot 1$ \\
\hline Total & $r$ & \multicolumn{4}{|c|}{$\varepsilon V, 0$} & \multicolumn{2}{|c|}{$r v, 0$} & \multicolumn{4}{|c|}{10} & - & - \\
\hline \multirow{2}{*}{$\begin{array}{l}\text { Strategic } \\
\text { Vision }\end{array}$} & $\begin{array}{l}: \text { X18 There is a } \\
\text { clear vision of } \\
\text { the college and } \\
\text { is known to all } \\
\text { staff }\end{array}$ & $r$ & 0 & $\begin{array}{l}1 \\
\text { r }\end{array}$ & $r$ & $\begin{array}{l}1 \\
v\end{array}$ & $\varepsilon r, 0$ & 9 & $r Y, 0$ & - & - & $r, I \vee 0$ & $\cdot, \Lambda \leq \mu$ \\
\hline & $\begin{array}{l}\text { X19: Senior } \\
\text { management } \\
\text { articulates its } \\
\text { strategic } \\
\text { direction with } \\
\text { high } \\
\text { transparency }\end{array}$ & $r$ & $\bullet$ & $\begin{array}{l}1 \\
7\end{array}$ & $\varepsilon$. & $\begin{array}{l}1 \\
.\end{array}$ & ro & 9 & $r Y, 0$ & $r$ & $v, 0$ & r, ro & $1, .77$ \\
\hline Average & - & - & $\bullet$ & - & ro & - & $\begin{array}{c}r, v \\
0\end{array}$ & - & $r r, 0$ & - & $r, v_{0}$ & $r, 10$ & $\cdot, 9 \circ \leq$ \\
\hline Total & $r$ & \multicolumn{4}{|c|}{$\varepsilon$. } & \multicolumn{2}{|c|}{ rr, vo } & \multicolumn{4}{|c|}{$r 7, Y 0$} & - & - \\
\hline \multirow{2}{*}{$\begin{array}{l}\text { Continuous } \\
\text { learning }\end{array}$} & $\begin{array}{l}\text { X20: } \\
\text { Continuous } \\
\text { learning } \\
\text { opportunities } \\
\text { and supplies } \\
\text { are provided } \\
\text { by } \\
\text { management. }\end{array}$ & - & - & $\frac{1}{9}$ & $\varepsilon V, 0$ & $\begin{array}{l}1 \\
y\end{array}$ & $r$. & 7 & 10 & $r$ & $v, 0$ & r, IVo & $\cdot, 90 \mathrm{~V}$ \\
\hline & $\begin{array}{l}\text { X21: There } \\
\text { are practical } \\
\text { and serious } \\
\text { procedures in } \\
\text { the subject of } \\
\text { continuous } \\
\text { learning. }\end{array}$ & - & - & ! & ro & $\begin{array}{l}1 \\
1\end{array}$ & $\leq 0$ & $\wedge$ & $r$. & $\varepsilon$ & 1. & $r, \wedge \bullet$. & $\cdot, q \times 1$ \\
\hline Average & - & - & - & - & $r q, r$ & - & $r v, 0$ & - & 18,0 & - & $\Lambda, \vee \bullet$ & $r, \cdot 1 r$ & $\cdot, 9 r q$ \\
\hline
\end{tabular}




\begin{tabular}{|c|c|c|c|c|c|c|c|c|c|c|c|c|c|}
\hline \multirow{3}{*}{ Sub-variant } & \multirow{3}{*}{ Indexes } & \multicolumn{10}{|c|}{ Scale movement } & \multirow{3}{*}{$\begin{array}{c}\text { Arithmeti } \\
\text { c mean } \\
0\end{array}$} & \multirow{3}{*}{$\begin{array}{c}\text { Standar } \\
\text { d } \\
\text { deviatio } \\
n \\
\varepsilon\end{array}$} \\
\hline & & \multicolumn{2}{|c|}{$\begin{array}{c}\text { Strongl } \\
\text { y agree } \\
\text { 。 }\end{array}$} & \multicolumn{2}{|c|}{$\begin{array}{c}\text { agree } \\
\leq\end{array}$} & \multicolumn{2}{|c|}{ Neutral } & \multicolumn{2}{|c|}{$\begin{array}{c}\text { Do not } \\
\text { agree } \\
r\end{array}$} & \multicolumn{2}{|c|}{$\begin{array}{c}\text { Strongly } \\
\text { Do not } \\
\text { agree } \\
\text {, }\end{array}$} & & \\
\hline & & ID & $\%$ & ID & $\%$ & ID & $\%$ & $\begin{array}{l}\text { I } \\
\text { D }\end{array}$ & $\%$ & $\begin{array}{l}\text { I } \\
\text { D }\end{array}$ & $\%$ & & \\
\hline & & & & & 0 & & & & & & & & \\
\hline Total & $r$ & \multicolumn{4}{|c|}{ ri, ro } & \multicolumn{2}{|c|}{$\mu v, 0$} & \multicolumn{4}{|c|}{$r q, Y 0$} & - & - \\
\hline \multirow[b]{2}{*}{$\begin{array}{c}\text { Smart } \\
\text { operations }\end{array}$} & $\begin{array}{l}\mathrm{X} 22: \text { The } \\
\text { college uses } \\
\text { modern } \\
\text { technologies in } \\
\text { the completion } \\
\text { of business }\end{array}$ & - & - & $\begin{array}{l}1 \\
1\end{array}$ & $r v, 0$ & $\begin{array}{l}r \\
1\end{array}$ & $\Delta r, 0$ & 7 & 10 & r & $\bullet$ & $r, r o$ & $\bullet, \Lambda \ldots$ \\
\hline & $\begin{array}{l}: \mathrm{X} 23 \text { There is a } \\
\text { rapid adaptation } \\
\text { to the external } \\
\text { environment } \\
\text { variables from } \\
\text { the } \\
\text { technological } \\
\text { side }\end{array}$ & - & - & $\begin{array}{l}1 \\
r\end{array}$ & r. & 1 & ro & $\checkmark$ & $1 V, 0$ & V & $1 V, 0$ & $r, \vee \vee 0$ & $1, \cdot V \mu$ \\
\hline Average & - & - & - & - & $\begin{array}{c}r \wedge, V \\
0\end{array}$ & - & $\begin{array}{c}\varepsilon r, V \\
0\end{array}$ & - & $\begin{array}{c}17, r \\
0\end{array}$ & - & $\begin{array}{c}11, r \\
0\end{array}$ & $r, q$ & - \\
\hline Total & $r$ & \multicolumn{4}{|c|}{$r \Lambda, V \bullet$} & \multicolumn{2}{|c|}{$\varepsilon \Psi, V \bullet$} & \multicolumn{4}{|c|}{$Y V, 0$} & - & - \\
\hline \multirow{2}{*}{$\begin{array}{c}\text { Collective } \\
\text { intelligence }\end{array}$} & $\begin{array}{l}\text { X24: The } \\
\text { team of the } \\
\text { college of } \\
\text { excellence } \\
\text { and } \\
\text { specialists }\end{array}$ & - & - & $\begin{array}{l}1 \\
1\end{array}$ & $r V, 0$ & $\begin{array}{l}r \\
r\end{array}$ & $\bullet \bullet$ & $\bullet$ & $1 Y, 0$ & $r$ & $\bullet$ & $r, \cdot 0$. & $\cdot, V \wedge r$ \\
\hline & $\begin{array}{l}\text { X25: There is } \\
\text { a general } \\
\text { atmosphere } \\
\text { that } \\
\text { encourages } \\
\text { creative } \\
\text { teamwork }\end{array}$ & - & - & $\begin{array}{l}1 \\
0\end{array}$ & $\mu v, 0$ & $\begin{array}{l}r \\
1\end{array}$ & $\bullet r, 0$ & $\varepsilon$ & 1 . & - & - & $r, r \vee \bullet$ & - , $7 \varepsilon$. \\
\hline Average & - & - & - & - & $r r, 0$ & - & $\begin{array}{c}\Delta r, V \\
0\end{array}$ & - & $\begin{array}{c}11,1 \\
0\end{array}$ & - & $r, 0$ & $r, 17 r$ & $\cdot, v 11$ \\
\hline Total & $r$ & \multicolumn{4}{|c|}{ 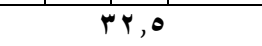 } & \multicolumn{2}{|c|}{ or, vo } & \multicolumn{4}{|c|}{ Ir, vo } & - & - \\
\hline Total index & 1. & \multicolumn{4}{|c|}{$F q, 71$} & \multicolumn{2}{|c|}{$\varepsilon r, Y)$} & \multicolumn{4}{|c|}{$r \cdot, 1 \Lambda$} & $r, 11 \varepsilon$ & $\cdot, \wedge \vee$. \\
\hline
\end{tabular}


Third: Testing the hypotheses of the study: The validity of the study hypotheses was as follows:

1. Test the first main hypothesis: there is a correlation between statistical information systems and the dimensions of the transition to smart universities at the macro level, as we note from table (5) that there is a significant correlation of significance between MIS and dimensions. The shift to smart universities at the macro level has reached a total correlation coefficient (** 0.702) which is a significant value at the level of significance (0.01), and this is a positive indication of acceptance of this hypothesis, so accept the first major hypothesis.

Table (5)

The relationship between management information systems and the dimensions of building smart universities.

\begin{tabular}{|c|c|}
\hline \hline Dependent variable & Mandependent variable \\
\hline \hline $\begin{array}{c}\text { the dimensions of building smart } \\
\text { universities }\end{array}$ & $\cdot, \vee \cdot r^{* *}$ \\
\hline \hline
\end{tabular}

For the purpose of establishing or denying the sub-hypotheses emanating from the first main hypothesis, this can be verified according to the following:

a. Test the first sub-hypothesis: there is a significant correlation between the human resources and the dimensions of the transition to smart universities, as it is clear from table (6) that there is a significant correlation between the human resources and the dimensions of the transition to smart universities with a correlation coefficient of $(* * 0.642)$ is a significant value at the level of significance (0.01), and this is a positive indication of acceptance of this hypothesis, so accept this first sub hypothesis.

b. Test the second sub-hypothesis, which states that there is a significant correlation between the material resources and the dimensions of the transition to smart universities, as we can see from table (6) that there is a significant correlation between the material resources and the dimensions of the transition to the smart universities. (0.646) is a significant value at the level of significance (0.01).

c. Testing the third sub-hypothesis, which states that there is a significant correlation between statistical resources and the dimensions of transition to smart universities. With a correlation coefficient of $(* * 0.490)$ which is a significant value at the level of significance (0.01), and this is a positive indicator of acceptance of this hypothesis, so accept this third hypothesis.

d. Test the fourth hypothesis which provides that there is a significant correlation between the data resources and the dimensions of the transition to smart universities. The correlation coefficient of $(* * 0.627)$, which is a significant value

TANMIYAT AL-RAFIDAIN (P-ISSN: 1609-591X; E-ISSN: 2664-276X) تنمية الرافدين 
at the level of significance (0.01), and this is a positive indicator of acceptance of this hypothesis, so accept this fourth hypothesis.

e. Sub-hypothesis test: which states that there is a significant correlation between the network resources and the dimensions of the transition to smart universities. The results of Table (6) confirm that there is a significant correlation between the network resources and the dimensions of the transition to smart universities. With a correlation coefficient of $* *(0.654)$ which is a significant value at the level of significance (0.01), and this is a positive indication of acceptance of this hypothesis, so accept this fifth hypothesis sub.

Table (6)

The correlation between each of the dimensions of MIS and the dimensions of transition to smart universities

\begin{tabular}{|c|c|c|c|c|c|}
\hline variable & \multicolumn{5}{|c|}{ Management information systems } \\
\hline & $\begin{array}{c}\text { Network } \\
\text { Resources }\end{array}$ & $\begin{array}{c}\text { Data } \\
\text { Resources }\end{array}$ & $\begin{array}{l}\text { Software } \\
\text { Resources }\end{array}$ & $\begin{array}{l}\text { Physical } \\
\text { Resources }\end{array}$ & $\begin{array}{c}\text { Human } \\
\text { Resources }\end{array}$ \\
\hline $\begin{array}{c}\text { And the } \\
\text { dimensions of } \\
\text { transition to smart } \\
\text { universities }\end{array}$ & $\cdot, 70 \leqslant * *$ & • オイV** & $\cdot, \leq ৭ . * *$ & $\cdot, 7 \leq 7 * *$ & $\cdot, \nearrow \leqslant Y * *$ \\
\hline
\end{tabular}

2. Test the second main hypothesis: there is a significant impact correlation statistically significant between management information systems and the dimensions of the transition to smart universities at the macro level, as we note from Table (7) there is a significant correlation effect between management information systems and strategic change This means that the independent variable (MIS) explains (69.4\%) of the changes in the adopted variable (the dimensions of the shift to smart universities) and that (30.6\%) of the changes are due to random variables cannot be controlled. This is confirmed by the calculated value of $\mathrm{T}$ (6.07) and the calculated value of $\mathrm{F}$ (37.03), which are significant values at a significant level (0.01).

TANMIYAT AL-RAFIDAIN (P-ISSN: 1609-591X; E-ISSN: 2664-276X) تنمية الرافدين 
Table 7

\section{Impact relationship between MIS Dimensions of transition to smart universities at the macro level}

\begin{tabular}{|c||c|c|c|}
\hline \multirow{2}{*}{$\begin{array}{l}\text { Dependent } \\
\text { Independent variable }\end{array}$} & \multicolumn{3}{|c|}{ Management information systems } \\
\cline { 2 - 4 } & T Calculated & F Calculated & $\mathbf{R}^{2}$ \\
\hline $\begin{array}{c}\text { Dimensions of transition to } \\
\text { smart universities }\end{array}$ & $\checkmark, \cdot V$ & $r v, r$ & $\cdot$, rqr \\
\hline
\end{tabular}

$P \leq 0.01, \quad D . F=(1.38), N=40$

For the purpose of proving or negating the sub-hypotheses resulting from the second main hypothesis, this can be verified as follows:

A- Test the first sub-hypothesis: which states that there is a significant impact correlation between human resources and the dimensions of the transition to smart universities. With a coefficient of determination of $\mathrm{R} 2$ of 0.513 , this means that the independent variable (human resources) accounts for $51.3 \%$ of the changes in the adopted variable (the dimensions of the shift to smart universities) and that $48.7 \%$ of the changes are due to uncontrollable random variables. This is confirmed by the calculated value of T (5.17), Value (F) calculated the amount of (26.78) and are two moral values at the abstract level (0.01) These results indicate the validity of this hypothesis, so accept this first sub-hypothesis.

B- Test the second sub-hypothesis: which provides a significant impact relationship statistically significant between material resources and the dimensions of the transition to smart universities, where the results of table (8) indicate that there is a significant relationship between the material resources and the dimensions of the transition to smart universities This means that the independent variable (material resources) explains (51.9\%) of the changes in the adopted variable (the dimensions of the shift to smart universities) and that (48.1\%) of the changes are due to random variables. Controllable, this is confirmed by the extreme calculated (T) value (5.23) and the calculated value (F) of (27.38) are significant values at the level of significance (0.01), and these results indicate the validity of this hypothesis, so accept this second hypothesis.

C- Testing the third sub-hypothesis, which states that there is a significant correlation effect between the software resources and the dimensions of the transformation to the smart universities. It is clear from table (8) that there is a significant significance effect between the software resources and the dimensions of the transformation to the smart universities. With a coefficient of R2 of 0.441 , this means that the independent variable (software resources) accounts for $44.1 \%$ of the changes in the adopted variable (the dimensions of the shift to smart universities) and that $55.9 \%$ of the changes are due to uncontrollable random

TANMIYAT AL-RAFIDAIN (P-ISSN: 1609-591X; E-ISSN: 2664-276X) تنمية الرافدين 
variables. This is confirmed by the calculated $(\mathrm{T})$ value of 4.47 , The calculated $(\mathrm{F})$ value of (12.08) are significant values at the level of significance (0.01).

D- Testing the fourth hypothesis which states that there is a significant statistical relationship between the data resources and the dimensions of the transition to smart universities. The results of Table (8) show that there is a significant relationship between the data resources and the dimensions of the transition to the smart universities. With a coefficient of R2 (0.495), this means that the independent variable (data resources) accounts for $49.5 \%$ of the changes in the adopted variable (the dimensions of the shift to smart universities) and that $50.5 \%$ of the changes are due to uncontrolled random variables. This is confirmed by the calculated value of T (4.97), and s Meh (F) calculated the amount of (24.78) and are two values at the abstract level $(0.01)$ These results indicate the validity of this hypothesis, so accept this sub-hypothesis fourth.

E- The fifth Sub-Hypothesis Test: This statistically significant correlation between the network resources and the dimensions of the transition to smart universities. This means that the independent variable (network resources) explains $(52.9 \%)$ of the changes in the adopted variable (the dimensions of the shift to smart universities) and that (47.1\%) of the changes are due to random variables. This is confirmed by the calculated (T) value of (5.34), and s The calculated value (F) of (28.99), which are significant values at the level of significance (0.01), and these results indicate the validity of this hypothesis, and therefore accept this fifth hypothesis.

\section{Table 8}

The impact relationship between each dimension of management information systems and the dimensions of transition to smart universities

\begin{tabular}{|c|c|c|c|}
\hline \multicolumn{3}{|c|}{ Dimensions of transition to smart universities } & \multirow{2}{*}{ Independent variable } \\
\hline T Calculated & F Calculated & $\mathbf{R}^{2}$ & \\
\hline $0,1 V$ & rı,VA &., $01 \pi$ & HR \\
\hline $0, Y r$ & rV,rN &., 019 & Physical resources \\
\hline ¿, §V & $\overline{l T, \cdot \Lambda}$ & ·,,$\leqslant \leqslant 1$ & Software resources \\
\hline$\varepsilon, 9 V$ & $T \Sigma, V \wedge$ & $\cdot, \leqslant 90$ & Data resources \\
\hline $0, r \leqslant$ & $r \wedge, 99$ &., $0 Y 9$ & Network resources \\
\hline
\end{tabular}

$P \leq 0.01, D . F=(1.38), N=40$

TANMIYAT AL-RAFIDAIN (P-ISSN: 1609-591X; E-ISSN: 2664-276X) تنمية الرافدين 


\section{Conclusions and suggestions}

\section{First: Conclusions:}

The study has come up with a number of conclusions, the most important of which are:

1. MIS has an important and effective role in the transition to smart universities.

2. There is a positive correlation between MIS and the dimensions of transition to smart universities.

3. There is a positive impact relationship between MIS and the dimensions of transition to smart universities.

4. The level of availability of management information systems in the researched college is an average level, which is somewhat low, especially in the business environment, which is characterized by the urgent need for new knowledge.

5. The availability of the variable dimensions of the transition to smart universities in the researched college is very low, and the college needs a higher level to keep pace with the contemporary business environment and continue to achieve success and growth.

6. There is a weakness in the adoption of each of the variables (software resources, data resources, and network resources) in the researched college.

\section{Second: Suggestions}

In the light of the findings of the study, the following main suggestions are:

1. The necessity of adopting the researched faculty of management information systems and consolidating its application in its work because of its great importance.

2. The need for the faculty to raise the level of management information systems to a higher level than it is, in order to be able to exercise its administrative, strategic and operational functions more efficiently and better effectiveness.

3. The researched college should strive to increase the availability of the dimensions of the transition to smart universities to a higher level than it is in the college because of the vitality, importance and role of this variable in the survival and continuity of the college.

4. The faculty should increase its interest in applying and activating each of the variables (software resources, data resources, and network resources).

5. The College must increase its interest in applying and activating each of the variables (understanding the environment, strategic vision, continuous learning,

TANMIYAT AL-RAFIDAIN (P-ISSN: 1609-591X; E-ISSN: 2664-276X) تنمية الرافدين 
smart operations, collective intelligence), in order to achieve the transition to smart universities.

6. The College should conduct an analysis of its competitive position continuously and diagnose and strengthen its strengths and weaknesses, especially in light of the intensification of competition.

\section{Bibliography}

\section{List of sources:}

1. Rababa'a, Khaled, 2016, Strategic Leadership and its Role in Building Intelligent Security Organizations Thesis, MA. Naif Arab University for Security Sciences, Riyadh.

2. Radaideh, Enas, 2016, The Impact of Smart Organization Characteristics in Crisis Management - An Empirical Study in Amman Private Hospitals. Master Thesis. Middle East University, Jordan.

3. Al-Otaibi, Ghassan Ahmad, and Khafaf, Maha Mahdi, 2012, decision support systems and smart systems, Dar Al-Hamed Publishing, Oman.

4. Abdo, Shuaib Mohammed, 2013, Designing the Production Decision Support System based on Electronic Spreadsheets, Master Thesis, Administration and Economics, University of Mosul, Iraq.

5. Ashour, Youssef, 2009 Effectiveness of Computerized Management Information Systems and their Impact in Crisis Management, Master Thesis, Islamic University, Gaza.

6. Al-Enezi, Saad, Saleh, Ahmad Ali, 2009, Intellectual Capital Management in Business Organizations, Azourdi Publishing House, Amman, Jordan.

7. Al-Awaini, Areej 2016, A proposed strategy for the transformation of Palestinian universities towards a smart university in the light of the requirements of the knowledge economy, Faculty of Education, Islamic University, Gaza.

8. Ghoneim, Ramzi Mohammed, 2017, the impact of the use of management information systems in promoting the building of smart organizations, Master Thesis, Islamic University, Gaza.

9. Yassin, Saad Ghaleb, 2009, Management Information Systems, Dar Azazuri for Publishing and Distribution, Amman.

10. Yassin, Saad Ghaleb, 2010, Analysis and Design of Information Systems, Dar Al-Manahj for Publishing and Distribution, Amman.

11. Yassin, Muthanna Saad, and Sharif, Shuaib Mohammed, 2018, The Role of Knowledge Management Systems in Achieving Strategic Change: An Analytical Study of the Opinions of a Sample of Administrative Leaders in the North Oil

TANMIYAT AL-RAFIDAIN (P-ISSN: 1609-591X; E-ISSN: 2664-276X) تنمية الرافدين 
Company / Kirkuk, Journal of Administration and Economics / Karbala, No. (26), Vol. 7).

12. Valacich, Joe, and Schneider, Christoph, (2010), Information Systems Today: Managing in the Digital World, Fourth Edition, Published by Prentice Hall.

13. bidgoli , (2012), management information system, publishing by Cengage Learning, Inc.

14. Effy, zo, (2009), management information systems, publishing by Cengage Learning, Inc.

15. Loudon, Kenneth, Loudon, Jane. (2010). Management Information System ,Systems, Managing The Digital Firm. 9th Edition, New Jersey: Prentice- Hall Inc.

16. Ng, J. W., Azarmi, N., Leida, M., Saffre, F., Afzal, A., \& Yoo, P. D., 2010, The Intelligent Campus (iCampus): "End-to-end learning lifecycle of a knowledge ecosystem", In Intelligent Environments (IE), 2010 Sixth International Conference on (332-337).

17. Wheelen, T \& Hunger, D. (2010). Strategic Management and Business Policy. 13th ed, Pearson: Prentice Hall, Upper Saddle River, U.S.A.

18. Buchanan, D and Huczynski, A. (2004). Organizational Behaviour: An Introductory Text. 5th edition. Prentice-Hall, Financial Time.

19. Liu, Y. L., Zhang, W. H., \& Dong, P. (2014). "Research on the Construction of Smart Campus Based on the Internet of Things and Cloud Computing". In Applied Mechanics and Materials, Vol. 543, 3213-3217.

20. http://ar.unesco.org/themes/education-21st. 